\title{
Corporate Responsibility in the UK Tourism Industry
}

\author{
Graham Miller \\ University of Westminster \\ 35 Marylebone Road \\ London \\ NW1 5LS \\ UK
}

Tel: +44 2079115000 ext: 3054

Fax: +442079115171

Email: G.Miller01@wmin.ac.uk 


\section{ABSTRACT}

This paper represents part of a programme of research into the development of indicators that can be used to monitor movement of the tourism industry with reference to more sustainable positions. In order to determine the potential for implementing such indicators this paper asked senior representatives of the UK tourism industry what factors influenced the degree of responsibility shown by their organisation. The research also asked what factors respondents felt would trigger any change in the actions of tour operators in the future. The research reveals that while many in the industry see industry structure as the constraining force, the potential for market advantage or the fear of negative PR also determines company actions. The research utilised elite interviewing for thirtyfive senior representatives of the UK tourism industry.

Key Words: Responsibility, tour operators, market advantage 


\section{$\underline{\text { INTRODUCTION }}$}

McKercher (1993) argues that for tourism to survive sustainability, the industry must become a proactive leader in shaping the debate on sustainability. Yet, tour operators contently constrained by their position as middlemen have long been a source of irascibility amongst critics who argue that the negative impacts of tourism are at least in part caused by the actions of operators who therefore have a responsibility to act. While all stakeholders have a responsibility to ensure the preservation of the Golden Goose and her eggs (Manning \& Dougherty, 1995), this paper concentrates on tour operators and what potential they have to behave in a more responsible manner. Understanding this potential is essential for the wider research programme to develop indicators that can measure movement towards a position of greater sustainability. If indicators of a more sustainable tourism industry are to be implemented, then industry co-operation and commitment towards a more responsible industry will be critical. The key research aims are therefore to determine which factors are currently encouraging or limiting tour operators to be more responsible and then to establish if these factors are likely to become more or less pressing in the future.

\section{LITERATURE REVIEW}

Jones et al (1997) estimated that there are approximately twelve million overseas package holidays sold each year in the UK, of which about $60 \%$ are controlled by the top five tour operators (Klemm \& Parkinson, 1999). Further, an attempted takeover bid would have increased the industrial concentration to just four had it 
not been for intervention by the European Union (EU). With eighty-five to ninety percent of package holidays booked through travel agents, the tour operators' control over the travel agents is a powerful influence over the industry as a whole. Forty percent of Lunn Poly's bookings for 1999 are for its parent company's Thomson holidays, thirty-eight percent of Going Places sales are for Airtours' holidays and thirty-one percent of Thomas Cook's sales for Sunworld (Heape, 1998). In addition to travel agents, each of the main tour operators has their own airline through which they process as much of the holiday traffic as possible. With this level of involvement in tourism, the tour operators have a significant interest in the survival of the industry, which should precipate more responsible actions. Yet, what are the factors that effect how responsible is the position taken by the tour operator?

\section{$\underline{\text { Industry Structure }}$}

It is perhaps surprising, given the above description of the UK outbound industry that Taylor (1996:388) describes the package tour industry as being "not sufficiently oligopolistic". The reasons cited for this interpretation are the relative ease of entry, the large number of firms that contest the market, the existence of merger activity and the instability of market share and profitability. Evans and Stabler (1995:260) believe that the problem has not been so much the shape of the industry (which conversely they believe to be oligopolistic), but the existence of excess capacity that gives the consumer "greater power to dictate the price that is paid. Consequently competition amongst tour operators is intensified. Thus, however much they wish to pursue profitability they are 
forced to engage in price wars to maintain market share and gain scale economies". This situation is exacerbated by the historically low prices that UK citizens have enjoyed for their holidays, which creates a powerful inertia. The implications for management of this industry structure are limited pricing freedom, which coupled with intensive competition and low customer loyalty leads to low profit margins. This in turn reduces the stability of the industry and so reduces incentives to make long-term investments. Against such a background taking steps to behave more responsibly has traditionally received a predictably low priority.

Ashworth and Goodall (1990) believe that in the case of the tour operator, the lack of responsibility is also a function of the lack of ownership and therefore control over the tourism services provided. This in turn enables tour operators to blame over-development on the local authorities and private developers who have caused the excess capacity. By virtue of the unique middle ground occupied, tour operators can claim to be simultaneously the innocent victim in satisfying existing consumer demand while helplessly responding to the existing supply stock.

\section{$\underline{\text { Legal Requirements }}$}

Legally the European Community Package Travel Directive, which was introduced in 1993 and implemented from 1993-1995 in member states (except Greece), requires that tour operators have legal minimum responsibilities, although these are primarily to the consumer (Downes, 1996). Roodman 
(1996:175) observes, "laws - not market forces - are what protect endangered species, manage nuclear waste and ban pollutants". Yet, the regulatory path is far from complete, Forsyth (1996:4) reports on a former managing director of a major tour operator admitting to the "virtual rape of Turkey" through his company's policies and another acknowledging that his actions were destroying regions but continued to do so because no-one told him to stop. For Forsyth (1996:4) there is no sense of responsibility, "tour operators seem to believe that they can sell as many holidays as they can in every destination - yet leave it to others to clean up the problems this causes".

\section{$\underline{\text { Market Advantage/ Negative PR }}$}

Ayala (1995) states the total global market for environmentally friendly products to be worth US\$200bn p.a. and rising rapidly, while the market for nature based tourism is predicted to be growing at between twenty-five and thirty percent annually to reach US\$300bn by 2000 (McBoyle, 1996). A Market Opinion Research International (MORI, 1997) survey of UK consumer attitudes to the environment and tourism showed $61 \%$ of consumers thought it was "very" or "fairly" important for any travel company that they dealt with to take into account environmental issues. This represented a rise of nine percentage points over the answers received to the same question when asked in 1995. Consumers also stated that they would be prepared to pay $£ 7.10$ (mean score) extra to ensure the tour operator they travelled with was committed to environmental protection and $£ 7.50$ for the same commitment from accommodation providers. 
Yet, a weakness of much of this research is the distinction between what survey respondents say and what they actually do (Maloney and Ward, 1973; Mansfeld, 1995; Williams, Shaw and Griffiths, 1996). Thus, a survey by Research International (The Observer 1996) of UK attitudes to green products that showed $90 \%$ of consumers wanted action to clarify the environmental boasts made by companies, can either be seen as a sign of real intent by consumers, or a view expressed in an ideal world. In the same survey $20 \%$ of respondents said they bought products because of the product information, or labelling. This would seem to be a more realistic figure for consumer involvement with product information, because although still open to dishonest answers, the question does ask the consumer about their actual purchasing behaviour rather than the slightly hypothetical question relating to what the consumer would like to see with regard to social commitment.

However, despite the wide definition of "green consumerism", the concept is far from having universal coverage amongst consumers. Consumers still buy products that they know fail to protect themselves or their families, and so it is an axiom that products are still consumed which fail to protect the wider world. McKercher (1993) also reminds us that the sixth fundamental truth about tourism is that tourists are consumers, not anthropologists and the seventh fundamental truth is that tourism is entertainment. Wight (1993:8) disagrees, "Consumers are switching allegiances, challenging traditional ethics, and actively seeking out products that are perceived to fulfil their needs, even if more costly. They do not look at the price of a product; they ask if there is an environmental or moral issue involved. Tourists as consumers, are asking questions, seeking creative travel 
alternatives, and are willing to pay extra to obtain the travel experiences they desire". Berry \& Ladkin (1997:439) in their study showed that although there was a mixed view from tourism entrepreneurs as to what sustainability was and who should be responsible there was a view that if the region of study could market itself as promoting sustainable tourism then "this would result in increased business".

Arguably, technology has a role to play in speeding the process through which responsible companies can be rewarded for their position and consumers can find out about companies with poor performance. Wade (1997) believes that computer technology can furnish the end-user with information in a more manageable form and even for the end-user to dictate the form in which they receive that information. Such an interactive and interrogative approach to information search represents the future of product declaration, and one that sits easily with the provision of market advantage to the better performing companies. Chandler (1999) reminds us that in addition to the potential for market advantage there is the "PR response" from the tour operators, which can influence their “perceived responsibility” (Curtin and Busby 1999:145).

\section{$\underline{\text { Cost Savings }}$}

Tibbs (1993) states that companies will rather spend time and money trying to diminish public sensitivity to the negative effects of their short termism than to adjust their behaviour and outlook to one with a more distant gaze. However, this position is one adopted not out of malice against the environment and society, 
but through clear economic reasoning. Any business will adopt a course of action until it is cheaper or more beneficial to adopt an alternative policy. Thus if it is cheaper individually to abuse the environment and pay any fines which are incurred than to adopt a policy of pollution control, then the environment will be abused (moral obligation aside). The World Commission for Economic Development (WCED, 1987:60) acknowledges that this is potentially and at least partly a role for public policy “...to ensure through incentives and disincentives, that commercial organisations find it worthwhile to take fuller account of environmental factors in the technologies they develop".

Here comparison with the cigarette industry can prove insightful because of the large and well-known tax levied on cigarettes in most countries ostensibly intended to reduce consumption. It can be contended that while the tax has made it more costly to smoke, the tax has done little to reduce the numbers of people smoking, evidenced by the growth in teenage females smoking, who, as a poorer section of society, one would expect to be the first to stop smoking if a tax was being effective. Yet, industry is more rational than teenage girls, and the negative behaviour (polluting) will be stopped when the marginal cost of doing so becomes greater than alternative courses of action (disposing of the waste properly). While this is indeed rational, the level at which this is reached will be dependent upon the elasticity of demand and supply for the product. Thus, Barrett (1991) predicts a carbon tax would have to increase taxes far beyond existing levels to see any tangible fall off of usage, and so similarly, any green taxes to reduce negative behaviour would by definition have to be introduced at a prohibitive level. Although it is disappointing that the consumer is urged to "go 
green" and pay more to do so, while we cannot expect business to "manage green" unless it is economically beneficial, it is also reassuring that this truism will hold and the economic arguments so often used to defend poor environmental performance i.e. it not being cost effective, can be used to protect the environment and society (Miller, 1997).

This philosophy is confirmed by Walley \& Whitehead (1994: quoted in Schnaiberg, 1997) "For all environmental issues, shareholder value, rather than compliance, emissions, or costs, is the central unifying metric. That approach is environmentally sound, but it is also hard headed, informed by business experience, and as a result, is much more likely to be truly sustainable over the long run". The economics of this position cannot be criticised and yet the message that conserving resources saves money has been a difficult one to sell, often because of the initial investment required to produce long term returns. Forsyth's (1995) study also concludes that although the existence of cost savings and the need to protect their long term investment should be sufficient incentive to adopt the principles of more responsible tourism, in practice this has not been the case and the concept does need a trigger to ignite interest. Thus the professionalism and short-term nature of the industry prevents it from taking a more responsible position.

\section{Moral Obligation}

Middleton and Hawkins (1998:107) list ten reasons for the private sector in the tourism industry to adopt more sustainable practices and yet deliberately exclude 
an ethical or moral argument because they "recognise that it features last and least for most tourism businesses in the 1990's, especially small businesses". Haywood (1993:235) concurs "Business and society are still seen as separate from each other, and the language of rights and responsibilities, which attempts to link the two remains irrelevant to the world of the practicing managers".

However, there are tour operators that achieve a necessary profit and act beyond the "moral minimum" (Smith, 1990). UK companies such as Explore have long traded from a position derived from their sense of moral duty to the places they visit, while larger companies like British Airways Holidays have also begun to implement policies based on a moral imperative. However, while in the case of several companies the morality shown is due to the personal sense of obligation felt by the owner/manager, more commonly the extent of the morality shown is a function of the responsibility that consumers expect companies to have. Yet, where this moral obligation is fuelled by consumer concern, then the consumer must have knowledge of the company's performance. For the tourism industry in particular, the consumer is largely lacking in information about the behaviour of tour operators and so what may be taken as a silent endorsement of a company policy could be simply a lack of knowledge. To cite consumer demand for cheap price holidays is to villainize the consumer when they are unaware of the tradeoffs that are being made in order to provide such a holiday. Greater accountability and information could serve to shift society's perception of where the moral minimum lay. 
It is possible however that times are changing. Gonsalves (1996:6) quotes the Control Risks Group; "The rise of global environmental activism in the past five years has left international business with nowhere to hide. If the late 1980's was the era of rapacious self-interest, the late 1990's will be the era of unprecedented accountability". "Unprecedented accountability" is not a terribly stringent requirement in the tourism industry, however the UN Commission on Sustainable Development (CSD) has made a start and the resolution from April 1999 "called upon" the industry to develop "voluntary initiatives in support of sustainable tourism development" that would "preferably exceed" any relevant standards (CSD 1999).

Thus, the industry structure, legal requirements, market advantage, potential for negative PR, cost savings and moral obligation are all potential factors influencing the responsibility shown by companies. The aim of this research is to explore which factors influencing the extent of responsibility shown by tour operators are the most influential and how likely it is in the future that the industry approach will change.

\section{METHODOLOGY}

In order to meet the research aims of determining what factors influence the level of responsibility shown by tour operators now and in the future, in-depth, semistructured, elite interviews were chosen as the preferred research method. Forsyth (1995), Curtin and Busby (1999), and Carey, Gountas and Gilbert (1997) in their studies of the UK tourism industry all use in-depth interviewing because 
of the control this approach affords the researcher over the interview. In-depth interviews also allow the respondent the opportunity to speak in their words on issues that they consider to be important rather than responding within the predetermined categories identified by the researcher, an important requirement for elite interviews.

Marshall and Rossman (1995) argue that elite interviewing allows the respondent to comment on the issue under discussion in relation to the overall view of the company and with regard to other organisations in the industry. Schoenberger (1991:180) extols the virtues of the corporate interview "in periods of economic and social change that challenge traditional analytical categories and theoretical principles". A problem with this research process however is that "the interviewer may have to rely on sponsorship, recommendations and introductions for assistance in making appointments with elite individuals" (Marshall and Rossman 1995:83). A further problem that Marshall and Rossman identify is the potential for the respondent to try and dominate the interview because of their experience and position in the industry. While this problem can be overcome by the skill of the interviewer, the low level of researcher input does provide an antidote against the potential charge of the researcher leading and influencing the respondent. Furthermore, improved validity in the study can be achieved in a face-to-face interview by enabling the researcher to instantly verify any comments which otherwise might be misunderstood or misinterpreted (FrankfortNachmias \& Nachmias, 1996). 
The research was concerned to attain a wide spread of opinion from across the tourism industry with a variety of perspectives. The sample of tour operators was taken from two sources. The Federation of Tour Operators (FTO) is a trade association that represents the largest of the UK tour operators and at the time of the research there were nineteen members. The Association of Independent Tour Operators (AITO) represents smaller and independent tour operators and at the time of the research there were over two hundred members. Each potential respondent was contacted via an initial phone call to identify the appropriate senior member of staff and was then sent a letter that explained the aim of the research and outlined the issues that the discussion would include. A phone call followed the arrival of the letter in order to arrange a date for the interview at a time convenient for the respondent. The sampling of five Non-Governmental Organisations (NGOs), three Trade Associations and the three Government departments with a responsibility for tourism was not random but judgemental, although otherwise followed the same methodology. Respondents were assured their comments would remain anonymous, and although it may further validate the findings by increasing transparency to reveal whom the respondents were, much of the material was received only on the repeated assurance that it would remain perfectly anonymous. Two companies during the research required that legal agreements be signed to this effect.

Table One shows the responses from the organisations approached. During the course of the interviews, an NGO that had been conducting similar interviews with tour operators commented on the difficulty experienced in securing interviews with senior personnel. While these problems do reflect Marshall and 
Rossman's warnings about the problem of trying to secure a meeting with elite members of an organisation, this research achieved a fifty-five percent response rate.

Insert Table One Here

The face-to-face interviews lasted between 45 and 90 minutes and where respondents were unable to meet in person then telephone interviews were conducted, these lasted between 20 and 40 minutes. It is an interesting feature of this research that respondents were able to answer questions on the telephone and yet did not feel able to fix a time for the researcher to come to their offices. This was especially the case with the National Tourism Organisations (NTOs).

To analyse the research, Ritchie and Spencer's (1994) framework for qualitative data analysis was followed. Using this five stage process, the researcher firstly "familiarises" himself with an overview of the research, and then identifies a "thematic framework" in which the material can be sifted and sorted. The third stage of the framework applies the framework and indexes the material using the framework and then charts the data through the use of headings and sub headings. The final stage maps and interprets data, completing a process designed to enhance the internal validity of research by improving the visibility and accessibility of the research. 


\section{$\underline{\text { RESULTS AND DISCUSSION }}$}

Figure One represents the reasons given by respondents in answer to questioning about the position they occupy with regard to taking more responsible action. While there does appear to be some kind of progression through meeting legal requirements, avoiding negative $\mathrm{PR}$, maximising market advantage, reducing costs and then to an altruistic position, all steps are bounded by the limitations of the industry structure. It is also accepted that companies will simultaneously occupy several, if not all, of these positions for the different products that they offer.

Insert Figure One Here 


\section{$\underline{\text { Reasons of Industry Structure }}$}

The limitations to the ability of tour operators to act responsibly identified through the research were the lack of control, "we don't take responsibility because we can't, because we can't control what is going on on the ground", the lack of finance "we know what to do but we just don't have the resources" and the problem of price dictating the market "I think that smaller tour operators are far more aware, but are powerless". Tourism is both blessed and blighted by the nature of its industry structure.

Given the large number of tourism organisations that are small companies with the original owners still firmly involved in the running of the company, it is perhaps not surprising that these people with a love of tourism are keen to act in a responsible manner and ensure that the product survives for others to enjoy. The small companies complained of being able to exert less control over the destination than the larger tour operators, or no control in several cases. They also complained of their inability to compete on price terms with the larger tour operators and so this resulted in lower profits because of the low volume carried, and this in turn reduced their ability to take proactive steps aimed at reducing impacts. However, the smaller companies were closer to the destinations they took passengers to and so had a heightened awareness of the problems, despite their impotence in creating solutions. The larger tour operators were seen as being financially able to take steps, but were so removed from the destination that they lacked awareness of the problems. 
Yet such a view is too simplistic, the small companies are not always good and the large companies not always bad. Many of the large companies had champions who were driving through a change in attitude amongst staff just as some of the small companies were guilty of sitting back and not tackling the issue. The dichotomy of how much responsibility to exercise mirrors much of the sustainability argument about the trade off between development and conservation in strong and weak sustainability (O'Riordan, 1981). One operator stated, “...there has to be a marriage between running and operating a successful and profitable business and a respect for the environment and preserving it" and while the truth of this cannot be disputed, the view of a government respondent has equal resonance, that "...at the end of the day, the action and the money are in the industry".

The view of non-tour operators was that, not withstanding the structure of the industry, the tour operators have the financial ability to take more responsible actions. While the role of the industry structure cannot be ignored, all the tour operators perhaps overplayed its significance as a reason for their inactivity.

\section{Legal Reasons}

On any given issue the company will firstly be concerned to meet any legal requirements that exist. As has already been discussed, the EC Package Travel Directive has ensured that tour operators take a greater responsibility for a number of issues, particularly for health and safety. The NTOs interviewed largely felt that the tour operators acted to the minimum point that they could get 
away with and that for many this meant the legal minimum. However, one small tour operator felt that the UK government did not want to increase the level of regulations surrounding tourism and that instead a more co-operative system of guidelines and frameworks would shape the behaviour of companies. If this is to be the case then firm commitments will need to be in place to ensure that companies do not just act to the minimum letter of the law. The view however that industry would automatically be opposed to any additional regulation was dismissed by one government respondent, who observed, “... Increasingly you find that companies are taking on voluntary codes of conduct, but the extent to which they are voluntary is questionable because they are pressurised by campaigning groups into doing that, so it is almost mandatory for them to do that. The question is what happens when you have a large company adopting a code, it then tries to pass on that code to its suppliers, so you have a ripple effect, and then you have the proliferation of codes at the moment. So increasingly we are hearing calls from businesses for at least a degree of minimum regulation in terms of standard statutes, so you have those companies that have invested a lot in developing their own codes and then you obviously have a whole lot of free riders who are less scrupulous and manage to get away with things. There is a need to bring everyone up to the same standards and the extent to which that needs to be regulated by government or whether industry are able to be self-regulating, the jury is still out at the moment".

Thus, companies might look to preserve their responsible advances in law in order that the irresponsible cannot reap the same advantages. This view assumes 
that there are benefits to be had from acting in a more responsible manner that need preserving and the advantage legally enshrining.

\section{$\underline{\text { Market Advantage/Negative PR reasons }}$}

One senior trade association respondent identified three reasons why a company might take a more responsible approach to its business. Firstly, the company could act out of the desire to achieve cost savings, secondly, to achieve market advantage and finally, they might act out of altruism. Yet the comment was often made that companies "could not afford to be seen to be slothenly with regard to environmental issues". A NTO observed that "tour operators need to be seen to be helping and being involved". Why was this? Why should the company not be left behind with regard to environmental issues? The implication seemed to be that market advantage would force companies to improve their performance and yet the evidence given by the tour operators of advantage accruing through environmental performance has been limited. One major tour operator commented

"We are saying that these twenty hotels...have got a good environmental record and you can make a choice, you can make a difference by going to this hotel - all other things being equal. But although we keep revisiting the figures, we can't prove that this has been the case yet".

Thus if market advantage is not the force which drives companies forward towards responsibility on the environment then the findings of this research suggest that it is negative PR that snaps at the heels of the worst performers. 
"The customers are demanding more, there has been so much hype and the media generating so much cynicism around package holiday market that I think that tour operators have changed, we have certainly changed". Whether the media can take full credit for this change, and whether the change is as pronounced as the tour operator quoted above believes is uncertain, however the following comment was made a disproportionate number of times. "If you ask tour operators what motivates them to act in this area, then one of the things that they are most scared of is being hauled up on Watchdog ${ }^{1,}$.

Thus, if the company feels that it will suffer from the barbs of consumer organisations and journalists, then it will have to improve its performance. If the company then feels that it can improve its performance sufficiently to capitalise through market advantage then this will become its strategy. Several respondents had adopted this position, although "the rest of us Joe Blogg tour operators out in the market place will do it, but only if it is worth it. If we could see that there would be some sustainable benefit to us from doing it then we probably would". It is an axiom that not all companies can gain market advantage from improved corporate responsibility and this was echoed in the view of one large tour operator. "I think that our view is that the way the world is going, the companies are having to become more responsible, so it doesn't actually give them advantage, it just helps them remain competitive, so they are going to have to do it".

\footnotetext{
1 "Watchdog" is a BBC consumer affairs TV programme which regularly attracts over eight million viewers
} 


\section{$\underline{\text { Cost Saving Reasons }}$}

Further corporate responsibility can be encouraged via the cost savings that improved environmental and social performances can bring. This was described by one major company as "fundamental to the business" and yet this was a view not commonly held and summed up well by the view of one tour operator, “...you tell them that they can save money but they might have to invest a little, and it all goes back to the professionalism of the Small and Medium-sized Enterprise (SME) sector in tourism and the difficulty of trying to persuade people who are making a half decent living as to why they should do it. You get the champions, the altruists if you like who pull other people along, but they tend to be few and far between". A smaller tour operator also dismissed the cost savings as a reason to take more responsible behaviour because of the often high initial investment required and felt that if more responsible action were to be taken it would be for more altruistic reasons. However, the same respondent later commented, "We are not crusaders, we are...very much aware of environmental issues, we do our small part, but we are not crusaders really and it is terribly difficult".

\section{$\underline{\text { Reasons of Moral Obligation }}$}

Socrates wrote "He who knows what good is will do good" and although it would be unwise to overestimate the role of altruism, it would equally be wrong to dismiss its role in the behaviour of tour operators. One large tour operator 
observed that the likes of Lufthansa, BA, Kuoni and Thomson "were not just looking at the issues commercially, but altruistically".

\section{IMPETUS FOR FUTURE CHANGE}

Respondents were asked where they felt that any impetus for future change in the industry might come from with regard to a change in the sense of responsibility. The complexities of the market were well understood by the elite interviewees and this made it difficult to categorise responses clearly. However common themes to answers received could be discerned, and these are shown in Table Two below.

Insert Table Two Here

The main theme was the number of respondents who felt that consumers would provide the initial trigger for the industry to take more responsible action. These answers were coupled with acknowledgement that other "levers of influence" would need to be pressed for progress to happen, but this group believed that the principle cause of action would be the consumer. "I think that it is probably going to be market driven...if companies are being requested, forced, identified as something which is of concern to their customers then they are more likely to do something about it. You already see that with British Airways holidays, Thomson, in other work where there is a greater degree of environmental awareness and that I am sure will increase as it has in continental Europe, so it will be the customer who drives the change". 
The second group felt that all stakeholders would need to act in unison for there to be any progress and that no single group would be likely to take unilateral action. "I don't think that it is down to just the tour operator and the consumer, obviously you have the governments too and the tourist boards". In addition, several tour operators were complementary of the more "assisting and consultative" approach that NGOs were increasingly taking in their dealings with the industry, although one concerned NGO was frequently criticised for its " sensationalist" posturing which threatened to ostracise it from holding a meaningful role. However, within the group of those who genuinely believed that simultaneous iterative steps across the industry was the best path to take, there were also those who felt that the very act of trying to move forward together would prevent any movement in that direction. Such a position enabled the respondents to argue for equal responsibilities and then to blame the other members of the partnership when no progress was made. The position taken by the tour operators here had close parallels with the "lack of control" cited by tour operators to explain their present position on responsibility.

The third category comprised exclusively of NTOs who felt that it was via the local or destination government that the tourism industry would display greater responsibility into the future. The NTOs acknowledged largely that consumer awareness was increasing but because of the attitude shown by tour operators the destination government needed to be in charge of any future changes in direction. 
Price and control were again cited by tour operators as factors that militated against tour operators taking the lead in any future developments. However, one leading tour operator believed that the argument of price as a determining factor was really an effect of poor customer loyalty and standards by tour operators in the past. "People just think that because they can't trust what they are being sold, then they will go for the cheapest option". The aim of that company was therefore to become the number one "customer-led" company in the industry, by which they meant being the most receptive to customer ideas. By doing so, the aim was to capitalise on what they perceived to be a marketing opportunity by giving the customer what the customer wanted rather than what had been contracted and then offered at a discounted price. Coupled with the responses from other tour operators there seemed to be a determination to move away from competing on price in the future, although it was acknowledged that all companies would still need to be competitively priced. Opinion was largely split over the effect that a large tour operator adopting environmental credentials would have on the rest of the industry. Some believed that it would take a large operator to seize the nettle and force the rest of the industry into following suit. Yet for others this was an unlikely scenario, "I can't see at this stage, or at any point in the near future, that any of them (the large operators) would, and even if one of them did I can't imagine that the others would necessarily follow unless all the consumers got behind that operator and I can't see that either". What was clear was that very few of the tour operators were about to take action without any pressure to do so from one source or another. 


\section{CONCLUSION}

This research aimed to determine what the key factors were to tour operators in adopting a more responsible stance both now and in the future. There was much criticism of the role played by tour operators from non-tour operators and much criticism of the large tour operators by the small tour operators. What this shows is the importance to the tourism industry of the tour operator and how the tour operators take their lead from the examples of the largest tour operators. Yet, a variety of other factors also influence the behaviour of companies, more work is needed to explore if the factors are linear or discrete in their effect.

What the interviews have shown is widespread support for the assertion that the consumer has a large potential to shape the future development of the tourism industry. This potential is largely through either the force of censure or the promise of marketing advantage and companies will need to monitor their performance accordingly. No organisation mentioned that the industry would improve its performance because of the potential for cost savings or an increase in altruism. The NTOs were keen for government to introduce strict controls over the tour operators, although all other respondents (including the UK government) except one saw this as being inappropriate. Whether the potential for consumerism would be realised was said to be a function of the increased importance of tourism in our lives and the level of awareness that consumers had about the real effects of the industry. Thus, the market can be said to offer the opportunity to trigger the industry into more responsible behaviour. This has two implications for the wider research objective of developing indicators to measure 
progress towards a more sustainable industry. Firstly, the tour operators will need to monitor in much greater depth their company performance in order that they can capitalise on any market potential, or just ensure they avoid negative publicity. Secondly, the information that indicators of sustainable tourism can provide would be of interest to a growing number of consumers in helping them to choose a tour operator. Such information would help to validate the claims made by tour operators about their holidays and potentially increase loyalty by tourists towards a particular tour operator. The long run benefits are available to tour operators from increasingly responsible behaviour, for tour operators unable to recognise this then increasingly responsible behaviour will also be needed in the future to avoid censure by consumers. 


\section{$\underline{\text { REFERENCES }}$}

Ashworth, G. and Goodall, B. (1990) Marketing Tourism Places. London, Routledge

Ayala, H. (1995) From Quality Product to Eco-Product: Will Fiji Set a Precedent? Tourism Management, 16, 1, 39-47

Barrett, J. (1991) Global Warming: Economics of a Carbon Tax. In Pearce, D., Barrett, S., Markandya, A., Barbier, E., Turner, R.Kerry., Swanson, T. (Eds) (1991) BluePrint 2. London, EarthScan, 31-52

Berry, S. and Ladkin, A. (1997) Sustainable Tourism: A Regional Perspective. Tourism Management, 18, 7, 433-440

CSD (1999) Commission on Sustainable Development. Seventh session, 19-30 ${ }^{\text {th }}$ April, New York

Carey, S., Gountas, Y., Gilbert, D. (1997) Tour Operators and Destination Sustainability. Tourism Management, 18, 7, 425-431

Chandler, P. (1999) Fair Trade in Tourism. Paper given at the "Achieving Fair Trade" conference, University of North London, $9^{\text {th }}$ June 1999

Curtin, S. and Busby, G. (1999) Sustainable Destination Development: The Tour Operator Perspective. International Journal of Tourism Research, 1, 135-147 
Downes, J.J. (1996) The Package Travel Directive - Implications for Organisers and Suppliers. Economic Intelligence Unit Travel and Tourism Analyst, 1, 78-92

Evans, N.G. and Stabler, M.J. (1995) A Future for the Package Tour Operator in the $21^{\text {st }}$ Century? Tourism Economics, $1,3,245-263$

Forsyth, T. (1995) Business Attitudes to Sustainable Tourism. Journal of Sustainable Tourism, December, 210-231

Forsyth, T. (1996) Bums on Seats. In Focus, Spring, 4-5

Frankfort-Nachmias, C. and Nachmias, D. (1996) Research Methods in the Social Sciences. London, Arnold

Gonsalves, P. (1996) Tourism: the Broader Picture. In Focus, Spring, 6-7

Haywood, K.M. (1993) Sustainable Development for Tourism: A Commentary with an Organisational Perspective. In Butler, R., Nelson. J., Wall.G. (Eds) Tourism and Sustainable Development: Monitoring, Planning and Managing, 233-241. University of Western, Canada, Department of Geography Publication Series

Heape, R. (1998) Tour Operator League Table. Tourism: The Journal of the Tourism Society, 98, 7 
Jones, P., Hudson, S., Costis, P. (1997) New Product Development in the UK Tour-Operating Industry. Progress in Tourism and Hospitality Research, 3, 283294

Klemm, M. and Parkinson, L. (1999) UK Tour Operators: Blessing or Blight. Paper given at the "Achieving Fair Trade" conference, University of North London, $9^{\text {th }}$ June 1999

Maloney, M. and Ward, M. (1973) Ecology: Let's Hear it From the People. American Psychologist, 28, 583-586

Manning, E.W. and Dougherty, T.D (1995) Sustainable Tourism: Preserving the Golden Goose. Cornell Hotel and Restaurant Administration Quarterly, April, $29-42$

Mansfeld, J. (1995) The "Value Stretch" Model and its Implication in Detecting Tourists' Class-Differentiated Destination Choice. Journal of Travel and Tourism Marketing, 4, 3, 71-92

Marshall, C. and Rossman, G.B. (1995) Designing Qualitative Research. London, Sage Publications

McBoyle, G. (1996) Green Tourism and Scottish Distilleries. Tourism Management, 17, 4, 255-263 
McKercher, B. (1993) Some Fundamental Truths about Tourism: Understanding Tourism's Social and Environmental Impacts. Journal of Sustainable Tourism, 1, $1,6-16$

Middleton, V.T.C. and Hawkins, R. (1998) Sustainable Tourism: A Marketing Perspective. Oxford, Heinemann-Butterworth

Miller, G. (1997) Approaches Towards Achieving Sustainable Tourism. MSc Dissertation. Unpublished, University of Surrey

MORI (1997) Green Behaviour - Sustainable Trends, Sustainable Lives? www.mori.com/pubinfo/green.htm, $10^{\text {th }}$ June 1999

O’Riordan, T. (1981) Environmentalism. London, Pion

Ritchie, J. and Spencer, L. (1994) Quality Data Analysis for Applied Policy Research. In Bryman, A., Burgess, R (Eds) Analysing Qualitative Data, London, Routledge, 173-194

Roodman, D.M. (1996) Harnessing the Market for the Environment. In Brown, L. (Ed) State of the World. London, Earthscan, 168-187 
Schnaiberg, A. (1997) Sustainable Development and the Treadmill of Production.

In Baker, S., Kousis, M., Richardson, D., Young, S. (Eds) The Politics of

Sustainable Development. London, Routledge, 72-90

Schoenberger, E. (1991) The Corporate Interview as a Research Method in Economic Geography. Professional Geographer, 43, 2, 180-189

Smith, N.C. (1990) Morality and the Market. London, Routledge

Taylor, P. (1996) Oligopoly or Contestable Markets in the UK Package Tour Industry. The Service Industries Journal, 16, 379-388

The Observer (1996) UK Attitudes to Green Products, $6^{\text {th }}$ June, 12

Tibbs, H. (1993) Industrial Ecology: An Environmental Agenda for Industry. Global Business Network, CA, Emeryville

Wade, J. (1997) Managing an Environmental Policy in a Resort Hotel. Paper presented to the EuroCHRIE/IAMS Conference: Hospitality Business Development Conference, Sheffield Hallam University, $13^{\text {th }}-15^{\text {th }}$ November World Commission for Economic Development (1987) Our Common Future. Oxford, Oxford University Press 
Wight, P. (1993) Ecotourism: Ethics or Eco-Sell? Journal of Travel Research, Winter, 3-9

Williams, A., Shaw, G., Griffiths, A. (1996) Tourism, Leisure, Nature Protection and Agri-Tourism: Principles, Partnerships and Practice. Sourcebook, European Partners for the Environment, Belgium 
Table One: Research Sample

Federation of Tour Operators Sampled $(n=19)$

Face to face interview conducted $(n=6)$

Telephone interview conducted $(n=1)$

Considered the research not relevant to the organisation $(n=3)$

Failed to return calls, faxes, emails and second letter $(n=8)$

Expressed regret at being too busy to co-operate $(n=1)$

Made redundant $(\mathrm{n}=1)$

Association of Tour Operators Sampled $(n=22)$

Face to face interview conducted $(n=7)$

Telephone interview conducted $(n=1)$

Considered the research not relevant to the organisation $(n=5)$

Failed to return calls, faxes, emails and second letter $(n=6)$

Expressed regret at being too busy to co-operate $(n=1)$

Made redundant $(\mathrm{n}=1)$

Non Governmental Organisations Sampled $(n=5)$

Face to face interview conducted $(n=5)$

Trade Associations Sampled $(n=3)$

Face to face interview conducted $(n=2)$

Expressed regret at being too busy to co-operate $(n=1)$

\section{Government Departments Sampled $(n=3)$}

Face to face interview conducted $(n=2)$

Informal discussion $(\mathrm{n}=1)$

\section{National Tourist Offices Sampled $(\mathrm{n}=\mathbf{2 0})$}

Face to face interview conducted $(n=1)$

Telephone interview conducted $(\mathrm{n}=10)$

Referred to Ministry for Tourism in the home country $(n=6)$

Failed to return calls, faxes, emails and second letter $(n=3)$ 
Figure One

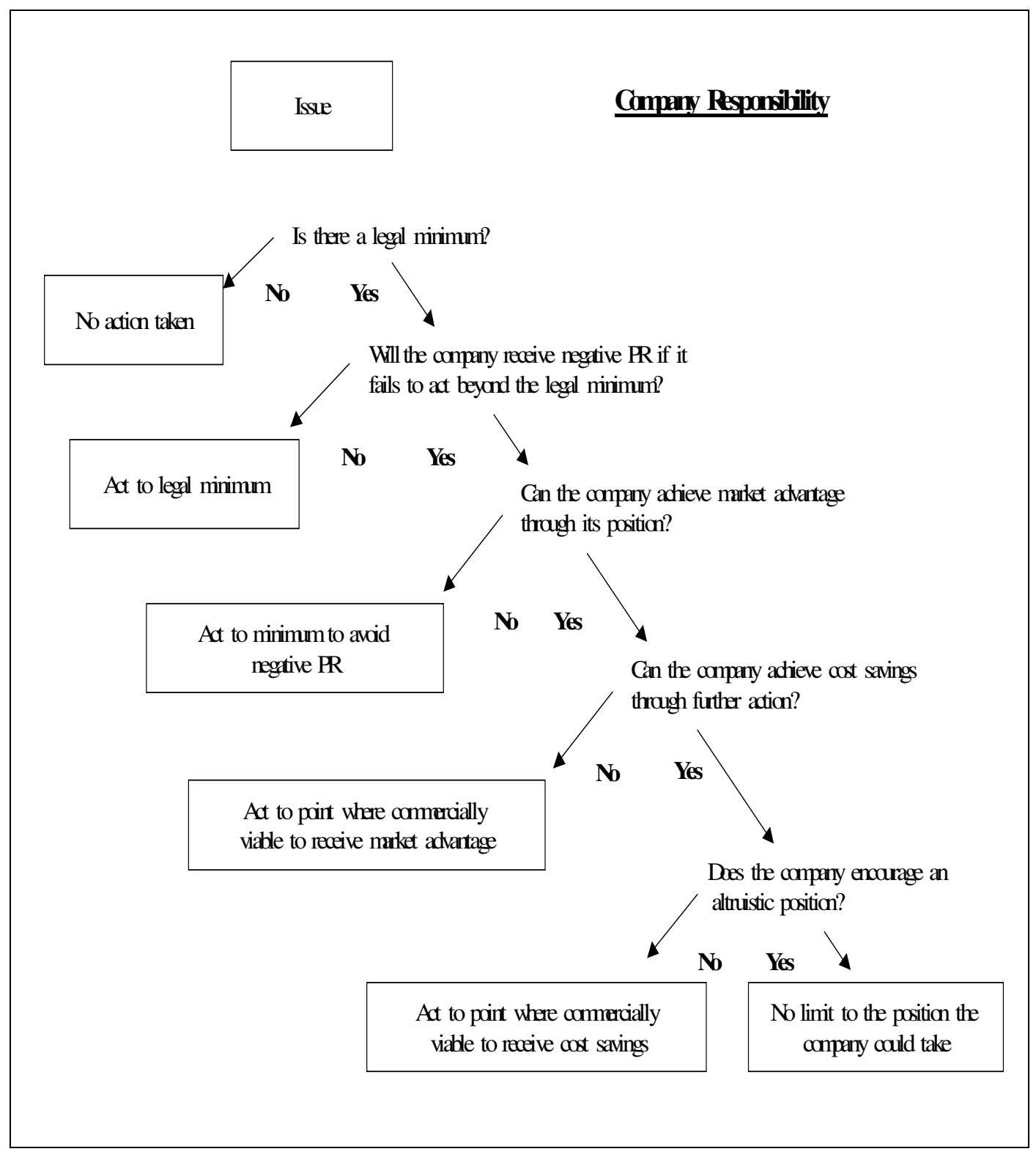


Table Two: Where will any future change in the tourism industry come from?

\begin{tabular}{|l|l|l|l|}
\hline & $\begin{array}{l}\text { Principally from } \\
\text { Consumers }\end{array}$ & $\begin{array}{l}\text { All stakeholders } \\
\text { acting in unison }\end{array}$ & $\begin{array}{l}\text { Principally from } \\
\text { government }\end{array}$ \\
\hline Tour Operators & 6 & 3 & \\
\hline NGOs & 3 & 2 & 7 \\
\hline NTOs & & & \\
\hline Trade Associations & 1 & 1 & \\
\hline Government & 1 & 1 & \\
\hline
\end{tabular}

